\title{
Artium
}

Architecture, Urbanism, Design and Construction Vol. 10, Issue 1, February 2022

Journal homepage: http://artium.hku.edu.tr

DOI: $10.51664 /$ artium.1018835

\section{İnşaat Projelerinde Kullanılan Proje Yönetim Tekniklerinin Analizi}

Rüveyda Kömürlü ${ }^{1}$, Onur Kuzu²,

1 Doç.Dr., Kocaeli Üniversitesi, Mimarlık ve Tasarım Fakültesi, Kocaeli, TÜRKIYYE ORCID ID:0000-0002-0665-481X

2 Yüksek Lisans Öğrencisi, Kocaeli Üniversitesi, Mimarlık Anabilim Dalı, Kocaeli, TÜRKIYE ORCID ID:0000-0002-4924-6613

\section{ÖZ}

Teknolojinin geçmişten günümüze kadar sürekli gelişmesi nedeniyle değişim ve büyüme halinde olan yapı sektörünün, süreç içerisinde yaşanan gelişmelerle beraber projelerin gittikçe karmaşık ve girift bir yapıya dönüştüğü görülmektedir. Bu nedenle yapı sektörü firmaları, projeleri koordineli bir şekilde optimum kalite, maliyet ve süre hedefinde tamamlamak için proje yönetimi ve tekniklerine ihtiyaç duymaktadırlar. Ancak, her projenin kendine özgü fiziki șartlar barındırması projelerin kendilerine özgü tekniklerle yürütülmesini ve yüklenici firmaları çeşitli proje yönetim tekniklerini kullanmaya zorunlu kılar. Dolayısıyla ilgili firma departmanlarının ve hâlâ geleneksel yöntemleri kullananların bu hususta yapı sektöründe genel olarak kullanılan yönetim tekniklerinin avantajlarını/dezavantajlarını ve kullanım yerlerini iyi bir şekilde tespit etmesi gerekmektedir. Bu çalışmada öncelikle proje yönetimi ve proje yönetim teknikleri ile ilgili kapsamlı bir literatür taraması yapılmış, bu doğrultuda inşaat sektöründe yaygın olarak kullanılan CPM, PERT ve Çubuk (Gantt) diyagramı proje yönetim teknikleri açıklanarak karşılaştırılmış, birbirlerine göre avantaj ve dezavantajları ile hangi projelerde kullanılacağı ortaya konmuştur. Aynı zamanda proje yönetimi ve proje yönetim tekniklerinin önemi ortaya koyularak inşaat sektöründe faaliyet gösteren firmalara ve bu konuda akademik çalışma yapan kişilere 1 şı tutması amaçlanmıştır.
Arassturma Makalesi Research Article

\section{Analysis of Project Management Techniques Used in Construction Projects}

\begin{abstract}
From past to present, the construction sector has been in a state of constant change and growth with the development of technology. With the developments in time, the projects have become more complex and intricate. For this reason, construction companies need project management and techniques to complete projects in a coordinated manner with the target of optimum quality, cost and time. However, due to the fact that each project has its own specific physical conditions, projects need to be executed with their own specific techniques and this obliges the contractors to use various project management techniques. Therefore, the relevant company departments which still use traditional methods should determine the advantages/disadvantages and usage areas of the management techniques generally used in the construction sector. In this study, an enhanced literature review has been performed about project management and project management techniques, and CPM, PERT and Gantt chart project management techniques, which are widely used in the construction industry, were explained and compared. Additionally, their advantages and disadvantages were revealed. Finally, to which project would a technique be applied is pointed. At the same time, it is aimed to shed light on the companies operating in the construction sector and people who do academic studies in this field by presenting the importance of project management and project management techniques.
\end{abstract}

MAKALE BILGISI

Gelis $04 / 11 / 2021$

Kabul $21 / 02 / 2022$

\begin{tabular}{l} 
ANAHTAR KELIMELER \\
\hline CPM \\
Çubuk (Gantt) diyagramı \\
PERT \\
Planlama \\
Proje yönetim teknikleri
\end{tabular}

ARTICLE HISTORY

Received $04 / 11 / 2021$

Accepted $21 / 02 / 2022$

KEYWORDS

CPM

Gantt chart

PERT

Planning

Project management

techniques

Atıf / Cited: Kömürlü. R. \& Kuzu, O. (2022). İnşaat Projelerinde Kullanılan Proje Yönetim Tekniklerinin Analizi. Artium, 10 (1): 45-53, https://doi.org/10.51664/artium.1018835 


\section{GIIRIŞ}

İnsanlığın barınma ihtiyacı ile ortaya çıkan, teknolojinin gelişimine paralel olarak zaman içerisinde toplumların artan istekleri ve talepleriyle beraber, gittikçe karmaşık bir hâl alan yapı sektörü, barındırdığı unsurlar ve dinamikler çerçevesinde ilgili sektör paydaşlarını birtakım değişiklikler yapmaya yöneltmiştir. Dünyada gittikçe hızlanan nüfus artışı, özellikle sanayi devrimi sonrası bölgesel yoğunlaşmalar sonucu arz-talep dengelerini bozmuştur. $\mathrm{Bu}$ doğrultuda, yapı sektörünün önemli bir paydaşı olan inşaat şirketleri, kâr marjını yükseltme hedefiyle projeleri optimum kalite, maliyet ve sürede tamamlamak üzere pozisyon almak durumunda kalmıştır (Copertari, 2002). Gün geçtikçe daha da karmaşık ve girift bir yapıya dönüşen sektörün farklı büyüklükte ve alandaki firmaların beraber çalışmasını gerektirmesi, projeler üzerindeki ilişkilerin artmasına ve projelerde yönetim zorluklarının ortaya çıkmasına yol açmıştır. İnşaat sektörü ve diğer disiplinler arasında artan bu ilişkiler, projelerin hedeflenen kalite, maliyet ve sürede tamamlaması ve proje paydaşlarının bir koordinasyon içerisinde verimli çalışması noktasında firmaların proje yönetimi ve proje yönetim tekniklerine gereksinimini artırmaktadır. $\mathrm{Bu}$ durum, proje yönetiminin ve proje yönetim tekniklerinin önemini günden güne artırmakta ve firmalar tarafindan yaygın bir şekilde kullanılmalarını zorunlu hale getirmektedir (PMBOK, 2013). İfade edilen gereksinimler ve gelişmeler doğrultusunda birçok inşaat firması küreselleşen dünyadaki artan rekabet ortamından olumsuz etkilenmemek için proje yönetimini ve CPM, PERT ve Gantt Diyagramları gibi teknikleri uygulamayı benimsemiştir. $\mathrm{Bu}$ sayede karmaşık yapıya sahip olan projelerde işlem öncelikleri ve önemlerine göre faaliyetlerin belirli aşamalara ayrılarak planlanması ve çeşitli teknikler ile kritik ve kritik olmayan işlemlerin belirlenmesi süreç içerisindeki organizasyonun yönetimini kolaylaştırarak projenin kalite, maliyet ve süre açısından belirlenen hedefe ulaşmak açısından önemlidir (Trietsch ve Baker, 2012). Ancak her projenin kendine özgü şartlar barındırması projelerin firmalar tarafindan kendilerine özgü tekniklerle ve stratejilerle yürütülmesini gerektirirken, proje yürütücüleri tarafından yanlış proje teknikleri ve yöntemlerinin seçilmesi, yüklenici firmanın hedeflediği kalite, maliyet ve süre anlamında olumsuz sonuçlar doğurabilmektedir. Dolayısıyla çalışmanın ana problemini oluşturan bu eksen kapsamında proje yönetiminin ve proje yönetim tekniklerini detaylı bir şekilde incelenmesi, CPM, PERT ve Gantt diyagramı tekniklerinin birbirlerine göre avantaj ve dezavantajlarının ortaya koyularak inşaat sektöründe proje yönetimi bağlamında değerlendirilmesi önem kazanmaktadır. Çalışmanın amacını teşkil eden bu yaklaşımla, çeşitli yazılı kaynaklarda yukarıda ifade edilen tekniklerle ilgili detaylı literatür taraması yapılmıştır. Erişilen kaynaklardan proje yönetimi ve teknikleri ile ilgili teorik bilgi edinilmiş, ardından bu konuda yapılan bazı saha çalışmalarının karşılaştırmalı analizi yapılmıştır. $\mathrm{Bu}$ doğrultuda, proje yönetimi ve tekniklerinin önemi, projenin hedefine ulaşmasına sağladığı yararları irdelenmiştir. $\mathrm{Bu}$ kapsamda, proje yönetimi ve tekniklerinin tanım ve özelliklerine göre hangi projelerde kullanılacağı ve avantaj-dezavantajları ortaya koyulmuştur.

\section{2. İNŞAAT PROJELERINDE PROJE YÖNETIMI}

\subsection{Proje ve Proje Yönetimi Kavramı}

Proje kavramı, yapılması planlanan işin, başlangıcından sonuna kadar tüm unsurlarıyla planlanıp oluşturulmasıyla ortaya çıkan düşünce ve dokümanların tümü olarak tanımlanabilir (Açıkel vd., 2013). Başka bir ifade ile proje, belirlenen bir sorunun optimum kalite, maliyet ve süre çerçevesinde programlanarak sorunun ortadan kaldırılmasını amaç edinen işlemleri kapsayan bir çalışmadır (Copertari, 2002). Bu tanımlardan yola çıkarak proje kavramı, başlangıç ve bitiş zamanı belli olan, belirlenen bir soruna yönelik çözümü ifade eden kendine ait özellikler barındırabilen işlemler bütünü olarak tanımlanabilir. Proje yönetimi ise bir projenin belirlenen hedefe ulaşması için projenin barındırdığı tüm faaliyetlerin belirli bir organizasyon içerisinde çeşitli tekniklerin uygulanarak yönetilmesi disiplinidir (PMBOK, 2013). Proje yönetimi, projelerin belirlenen hedefe ve amaca ulaşması için ayrılan kaynakların çeşitli tekniklerle planlanarak üretimin gerçekleştirilmesi olarak da tanımlanabilir (Kömürlü ve Toltar, 2018). Özetle, proje kaynaklarını verimli şekilde kullanarak hedeflenen kalite, maliyet ve sürede tamamlamak için uygun tekniklerle ve araçlarla süreçlerin planlamasını ve uygulamasını yapmaktır. Başarılı bir proje yönetimi; projenin iyi bir şekilde ifade edilmesine, uygun stratejinin ve organizasyonun seçilmesine, işveren/müşteri isteklerinin doğru bir şekilde tanımlanmasına, paydaşlar arası ilişki ve koordinasyonun sağlanmasına bağlıdır.

\subsection{Proje Yönetimi Evreleri}

İnşaat projelerinde proje yönetimi evreleri, aralarında devamlı bir ilişki bulunan ve birbirlerini tamamlayan 5 ayrı evreden oluşmaktadır. Bu evreler aşama sırasına göre şöyledir;

1) Başlatma Evresi: Bu evrede proje çerçevesi belirlenip gerekli fizibilite etütleri ve değerlendirmeler yapılır. Yapılan kaynak tedariği, maliyet ve organizasyon çalışmaları sonucunda projenin stratejisi oluşturulur (Coşkun ve Ekmekçi, 2012).

2) Planlama Evresi: Projenin tamamlanması için yapılması gerekenlerin planlandığı, proje paydaşlarına proje organizasyonu ve stratejisinin detaylı şekilde sunulduğu evredir (Kerzner, 2003). Ayrıca uygulamaya geçilmeden önce projenin gerekçelerinin, amaçlarının, yöntemlerinin ve hedeflerinin belirlendiği evredir.

3) Uygulama Evresi: Gerekçeleri, amaçları, yöntemleri ve hedefleri belirlenen projenin yapımına başlandığı evredir (Gültekin, 2007). Ayrıca diğer evrelere kıyasla işçi istihdamı ve 
işgücü ihtiyacı, uygulama evresinde en üst seviyeye çıkmaktadır.

4) Kontrol Evresi: Uygulama evresinin çeşitli araçlarla periyodik olarak takip edildiği evredir. Planlaması yapılan projenin uygulama süresince oluşan sapmalarının belirlenmesi gerekmektedir. Çeşitli kontrol mekanizmalarıyla elde edilen bulgularin, projeye olumlu ya da olumsuz etkisinin saptanması ve saptanan bu bulguların etkisinin analiz edilip proje planının kalite, maliyet ve süre kriterlerine göre düzeltilip uygulanmasidir (Cleland ve Ireland, 2002).

5) Sonlandırma Evresi: Projenin tamamlanarak proje paydaşlarının aralarındaki sözleşmelerin bittiği ve ilişkilerin sonlandırıldığı evredir. Ayrıca yapılan proje değerlendirilerek projenin hedefe ulaşmasındaki başarısı ölçülür (Coşkun ve Ekmekçi, 2012).

$\mathrm{Bu}$ evre ve işlemler, birbirini takip ediyor gibi planlanıp uygulanmakla birlikte, bunlar arasında kesin bir ayrım yapılamamaktadır. Şekil 1, proje başlangıcından bitimine kadar olan süreçte proje evrelerinde yapılan işlemlerin yoğunluğu ile başlangıç ve bitiş zamanlarını göstermektedir. Bunlardan kontrol ve uygulama aşamaları en fazla zamanı alırken başlangıç ve sonlandırma aşamaları en kısa zamanı almaktadır. Ayrıca en fazla aktivite seviyesine sahip aşamanın uygulama aşaması olduğu da görülebilmektedir. Her aşamada olduğu gibi, aktivite yoğunluğu belirli bir ivmeyle artarak zirveye ulaşır, ardından belirli bir ivme ile azalır.

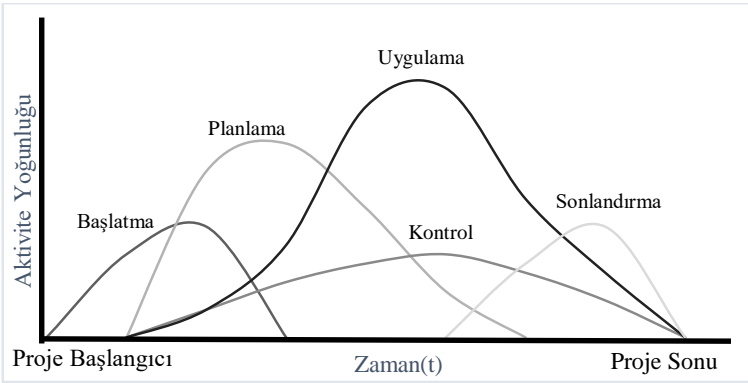

Şekil 1. Proje Yönetimi Evreleri ve Süre İlişkisi (PMBOK, 2013).

\section{PROJE YÖNETIMI TEKNIKLERI}

Planlama, herhangi bir projenin optimum kalite, maliyet ve sürede gerçekleştirilebilmesi için, başlangıçtan sona kadar tüm iş kalemlerinin belirli bir zaman aralığında ve düzen içerisinde koordine edilmesi işlemidir. Eğer bu iş kalemleri tekrar eden, karmaşık olmayan basit işler ise planlama için izlenecek yol haritasına kolaylıkla karar verilebilmektedir. Ancak iş kalemlerinin fazla sayıda olması ve girift bağlantılar içermesi projeyi karmaşık hale getirmekte ve projenin yönetimini zorlaştırmaktadır. Dolayısıyla bu tip zor durumlarla karşılaşıldığında iş kalemlerinin ve bağlantılarının detaylı incelenmesi ile bir iş dökümü oluşturmak ve bu işleri, proje hedefine ulaşmak üzere planlamak gerekmektedir (Ünder, 2006). Özetle; kalite, maliyet ve süre boyutları açısından büyük hacimli ve karmaşık olan inşaat projelerinin yönetiminde iş programı ve yönetim teknikleri çok önemlidir. Çünkü projenin belirlenen zaman aralığında tamamlanabilmesi için uygulama sırasındaki işlemlerin önceliği, entegrasyonu, koordinasyonu ve projeye olumlu/olumsuz etkisinin yönetilmesi için çeşitli proje yönetim teknikleri kullanılmaktadır.

Günümüzdeki modern proje yönetimi kavramının geçmişi 1900'lü yılların başındaki çalışmalara dayanmakla birlikte bazı otoriteler proje yönetimini, Çin Seddi ve Misır Piramitleri gibi eserlerin yapım dönemine kadar dayandırmaktadır. Dolayısıyla tarih öncesi dönemlerde yapılmış olan bu projelerde de dönemin imkânlarına ve kurallarına özgü yönetim teknikleri de beraberinde uygulanmıştır. Modern anlamdaki proje yönetim teknikleri ise özellikle sanayi devrimi ve sonrası dönemlerinde, teknolojinin hızla gelişmesi ve var olan mevcut yönetim tekniklerinin sorunlara çözüm bulamaması nedeniyle 1900'lü yılların başlarında ortaya çıkmaya başlamıştır (Kır, 2007). Özellikle 19. yüzyılda yapılan büyük ölçekli projeler söz konusu tekniklerin gelişiminde önemli rol oynamıştır. Bu bağlamda proje yönetimi ve teknikleri ile ilgili ilk bilimsel çalışmalar 20. yüzyıl başlarında Frederick Taylor tarafindan yapılmıştır. Taylor, daha çok geleneksel yöntemler kullanılarak planlaması yapılan projelerin, bilime dayanan yeni yönetim anlayışı ile daha etkili bir şekilde yapılabileceğini ortaya koymuştur. Taylor'un geliştirdiği bu yeni yönetim anlayışından önce projelerdeki verimliliğin artırılması için işçilerin beden gücünden maksimum seviyede yararlanılması görüşü yaygındır. Taylor ise projedeki her adımı ve işlemi spesifik olarak inceleyerek projelerdeki verimliliği artırmayı hedeflemiştir. Küreselleşen dünyada projelerin önceki yıllara göre gittikçe daha karmaşı ve kapsamlı hal alması proje yönetimi ve tekniklerinin gelişmesine neden olmuştur. Bu bağlamda 1917 yılında Henry Gantt tarafından projelerin iş akışının ve faaliyetlerinin basit bir şekilde yönetilmesine imkân veren modern tekniklerden biri olan Gantt Diyagramı geliştirilmiştir. Sonrasında, İkinci Dünya Savaşı sırasında gelişen sanayi faaliyetleri ile azalan nüfus ve beraberinde getirdiği işgücü sorunu, şirketleri gelişmiş yeni proje yönetim tekniklerinin uygulanmasına yönlendirmiştir. Bu doğrultuda 1956-1958 yıllarında, temel işleyiş mantığını Gantt diyagramından alan ve halâ daha yaygın olarak kullanılan CPM ve PERT diyagramları geliştirilmiştir (Kır, 2007).

$\mathrm{Bu}$ bağlamda yaygın olarak kullanılan başlıca proje yönetim teknikleri şunlardır:

1) Çubuk (Gantt) Diyagramları

2) Ağ (Şebeke) Diyagramları

- PERT - Program Değerlendirme ve İnceleme Yöntemi (Program Evaluation and Review Technique)

- CPM - Kritik Yol Yöntemi (Critical Path Method)

3) Kutu Diyagramları

4) Denge ve Devre Diyagramlariyla Planlama

5) Kaynak Dağılımı ve Kaynak Atama Yöntemleri (Resource Allocation / Resource Assignment)

$\mathrm{Bu}$ teknikler arasında inşaat sektöründe en yaygın olarak kullanılan CPM, PERT ve Gantt diyagramı teknikleridir. 


\section{1. Çubuk (Gannt) Diyagramları}

Modern proje yönetiminde kullanılan ilk yöntem, Henry Gannt tarafindan 1917 yılında geliștirilen Çubuk (Gannt) diyagramlarıdır (Ünder, 2006). Gantt diyagramı çoklu parametreler içermediğinden küçük hacimli ve karmaşık olmayan projeleri tanımlamak, izlemek ve rapor etmek için kullanılmaktadır (Temel, 2011). Bu yöntemde, işlemlerin başlangıcı, süresi, bitişi ve projedeki işlemlerin adları yazılır (Şekil 2). Çubukların büyüklüğü işlemin süresiyle doğru orantılıdır. Bu tekniğin hızlı ve kolay uygulanabilmesi bu tekniğin günümüzde de kullanılmasını mümkün kılmaktadır. $\mathrm{Bu}$ yöntem doğru kullanılması halinde iş akışını yönetmek ve problemleri tespit etmek için kullanılabilir. Bununla birlikte, çok farklı parametreler içeren kapsamlı projelerde kullanılması sağlıklı sonuçlar vermemektedir.

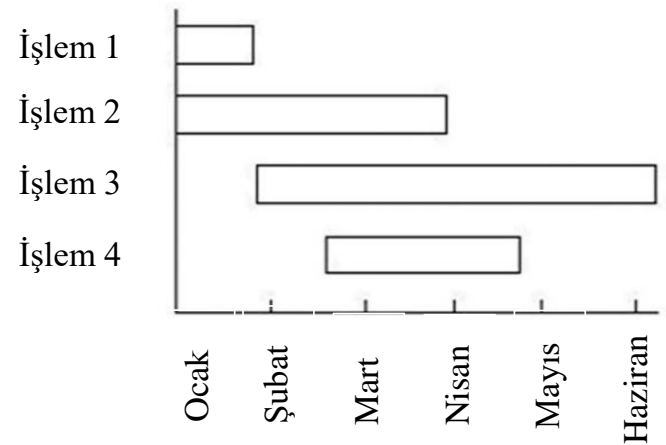

Şekil 2. Örnek Gantt Diyagramı (PMBOK, 2000).

Çubuk (Gannt) diyagramlarını doldurma, blok ve sembol yöntemi olarak üç farklı şekilde hazırlamak mümkündür.

\section{- Doldurma Yöntemi}

Bu yöntemde, projenin başından sonuna kadar olan süreçte yapılacak olan her işlem kendi içinde alt işlemlere ayrılmaktadır. Projede yapılan işlemler planlanan ve gerçekleşeni ifade eden yatay çubuklar ile gösterilmektedir. Yatay çubukların altına yazılan harfler alt işlemleri simgelemektedir (Şekil 3). Bu durum projedeki işlemlerin etkin bir şekilde kontrol edilmesini sağlamaktadır (Albayrak, 2009).

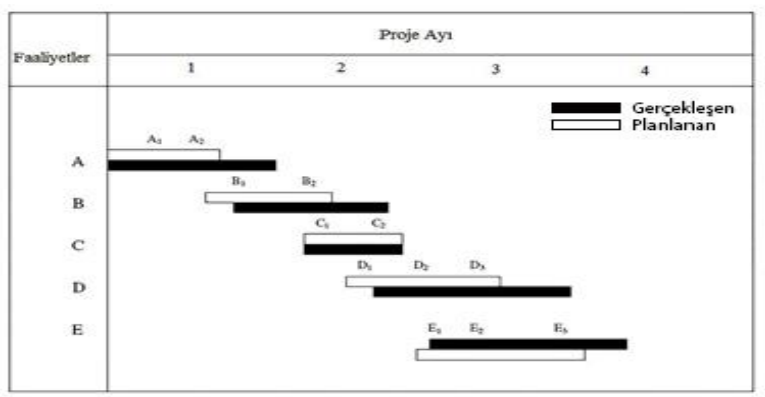

Şekil 3. Gantt Diyagramının Doldurma Yöntemi ile Gösterimi (Temel, 2011).

\section{- Blok Yöntemi}

$\mathrm{Bu}$ yöntemde, projede yapılacak işlemler bloklar ile ifade edilmektedir. İşlemlerin planlanan ve gerçekleşen başlangıç ve bitiş tarihleri ifade edildiği için kullanıcıya aynı zamanda bir iş programı da sunmuş olmaktadır. Günümüzde Çubuk Diyagramı genel olarak bu gösterim şekli ile kullanılmaktadır (Albayrak, 2009).

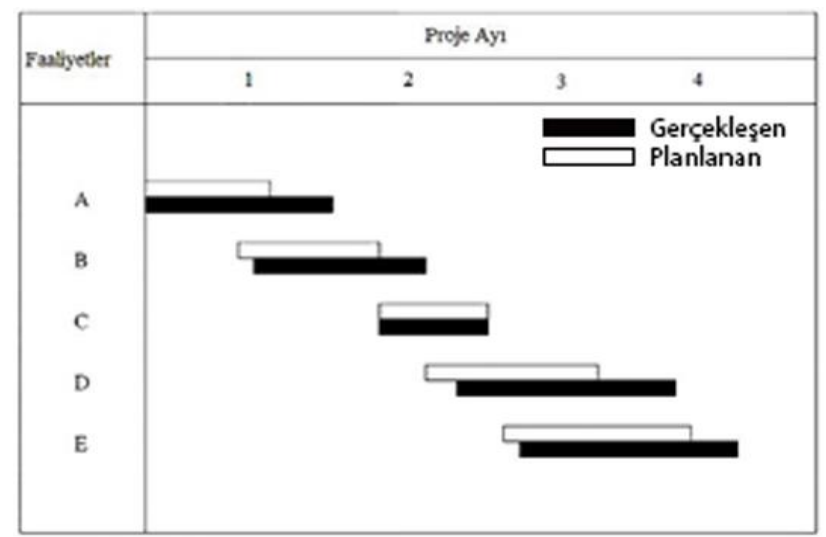

Şekil 4. Gantt Diyagramının Blok Yöntemi ile Gösterimi (Temel, 2011).

\section{- Sembol Yöntemi}

$\mathrm{Bu}$ yöntemde, projede yapılacak işlemler semboller ile ifade edilmektedir. İşlemlerin planlanan ve gerçekleşen başlangıç ve bitiş tarihleri ifade edildiği için kullanıcıya aynı zamanda bir iş programı da sunmuş olmaktadır (Şekil 5). Projede planlanan ve gerçekleşen işlemler içi dolu veya boş üçgenlerle gösterilmektedir (Albayrak, 2009).

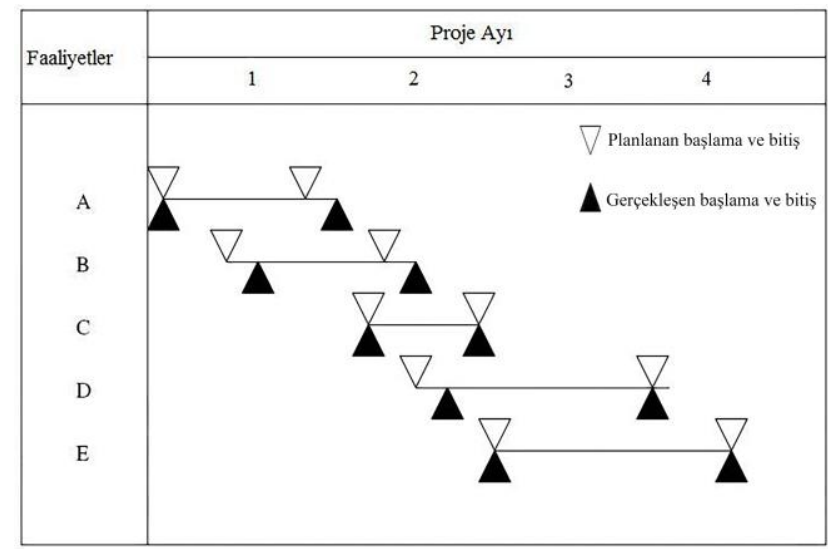

Şekil 5. Gantt Diyagramının Sembol Yöntemi ile Gösterimi (Temel, 2011).

İfade edilen Gantt (Çubuk) diyagramı yöntemi, diğer proje yönetim teknikleri gibi inşaat projelerinde hâlâ kullanılmaktadır. Ancak bu teknik, yapılan projenin detaylarına ve şartlarına bağlı olarak bazı noktalarda kullanıcıya üstünlük sağlamaktayken bazı noktalarda yetersiz kalmaktadır (Tablo 1). 
Tablo 1. Çubuk (Gantt) Diyagramının Üstünlük ve Zayıflıkları (Coşkun ve Ekmekçi, 2012, Ünder, 2006, Taxen ve Lilliesköld, 2008, Starr, 1996, Temel, 2011).

\begin{tabular}{|c|c|}
\hline ÜSTÜNLÜKLER & ZAYIFLIKLAR \\
\hline $\begin{array}{l}\text { Hazırlanışı pratik ve hızlı, } \\
\text { kullanımı basit olduğundan } \\
\text { uygun bir yöntemdir. }\end{array}$ & $\begin{array}{lr}\text { Faaliyet aşamaları arasındaki } \\
\text { zayıf ilişkileri ve ortaya } \\
\text { çıabilecek } & \text { sorunları } \\
\text { tanımlamaz. } & \\
\end{array}$ \\
\hline $\begin{array}{l}\text { Tüm iş kalemleri liste } \\
\text { şeklinde görülür. }\end{array}$ & $\begin{array}{l}\text { İş miktarını yapılan işlemlere } \\
\text { bağlı göstermez. }\end{array}$ \\
\hline $\begin{array}{l}\text { Yapılacak olan bütün } \\
\text { işlemlerin başlangıç ve bitiş } \\
\text { tarihi bellidir. }\end{array}$ & $\begin{array}{l}\text { Olasılık arz eden işlemlerde } \\
\text { kullanılmazlar. Kritik işlemlerin } \\
\text { belli olmaması projenin } \\
\text { gecikmesine neden olabilir. }\end{array}$ \\
\hline $\begin{array}{ll}\text { İşlemlerin süresi } & \text { bellidir. } \\
\text { Hazırlanma } & \text { maliyeti } \\
\text { oldukça azdır. } & \\
\end{array}$ & $\begin{array}{l}\text { Proje süresinin kısaltılması ile } \\
\text { maliyetin nası değişeceğini } \\
\text { açılamaz. }\end{array}$ \\
\hline $\begin{array}{lr}\begin{array}{l}\text { Değiştirilmesi } \\
\text { güncellenmesi }\end{array} & \text { ve } \\
\text { olduğundan } & \text { basit velay } \\
\text { olasillğ } & \text { bulunmayan } \\
\text { projelerde } & \text { kullanıma } \\
\text { uygundur. } & \end{array}$ & $\begin{array}{l}\text { Projelerin hedefe uygun } \\
\text { tamamlanması için önemli olan } \\
\text { kritik ve kritik olmayan } \\
\text { işlemlerin ayrımını yapamaz. }\end{array}$ \\
\hline
\end{tabular}

\subsection{A $\breve{g}$ (Şebeke) Diyagramları}

İnşaat sektörü paydaşları, projelerin optimum kalite, maliyet ve sürede tamamlanmasını hedeflemektedir. Ancak inşaat projelerinin yapısı gereği içerisinde oldukça fazla işlem ve faaliyet barındırması proje sürecinin planlanmasını ve hedeflere ulaşmayı zorlaştırmaktadır. Dolayısıyla projelerdeki işlem ve faaliyetlerin ilişkisi dikkatle incelenip kontrol altında tutulmalıdır (Yıldiz, 2015). Bu nedenle sektörün gereksinimleri doğrultusunda A $\breve{g}$ (Şebeke) diyagramları geliştirilmiştir. Bu yöntemle, projelerde birbiriyle ilişiği olan işlemler oklar ve düğüm noktaları yardımı ile çizilmekte ve işlemler optimum şekilde sıralanıp bir diyagram şeklinde gösterilmektedir. Projelerin planlanması ve izlenebilmesi amacıyla geliştirilen ve modern planlama teknikleri olan PERT (Program Evaluation and Review Technique) ve CPM (Critical Path Method) yaygın olarak kullanılmaktadır. Bu teknikler 1957-1958 yıllarında geliştirilmiş olup temellerini Gannt Diyagramı oluşturmaktadır. CPM ve PERT teknikleri genellikle büyük hacimli, fazla zaman alan ve tek defaya mahsus projelerin iş akışının planlanmasında kullanılmaktadır. Projelerde işlem sürelerinin hesaplanmasında; PERT tekniğinde olasılık dikkate alınırken CPM tekniğinde zamansal varsayımlar dikkate alınmaktadır (Trietsch ve Baker, 2012). Bu bağlamda CPM ve PERT teknikleri üç evreden oluşmaktadır (Halaç, 2001):

1) Planlama Evresi: Projede bulunan işlemler kategorize edildikten sonra süreleri olasılık/varsayımsal olarak tahmin edilir. Ardından işlemler arasında öncelik sırasına göre oluşturulan bir ağ diyagramı çizilir. Bu aşama, kategorize edilen işlemlerin detaylı bir şekilde incelenmesi imkânı sunmaktadır.
2) Programlama Evresi: Bu evrede yapılması planlanan işlemler arasındaki zamansal ilişki diyagram olarak ifade edilir. $\mathrm{Bu}$ diyagram projede yapılması gereken kritik işlemleri de gösterdiği için projenin istenen sürede tamamlanmasına yardımcı olmaktadır.

3) Kontrol Aşaması: Zaman diyagramları ile periyodik olarak projenin ilerleme raporları hazırlanır. Kısacası bu evrede proje analiz edilir ve eğer sapma durumunda güncelleme yapılmaktadır.

\section{PERT-Seçenekli Değerlendirme Yöntemi}

Temeli Gantt Diyagramlarına dayanan PERT tekniği, işlemler arasındaki ilişkileri Gantt Diyagramına göre daha iyi bir şekilde tanımladığı için bu tekniğin gelişmişsi olarak değerlendirilmektedir (Yıldız, 2015). Bu tekniğin kullanıldığı ilk önemli uygulama, ABD Deniz Kuvvetlerine ait Polaris füzeleri projesidir. $\mathrm{Bu}$ projede PERT tekniğinin başarıyla uygulanması sonucu proje hedeflenenden 2 yıl önce tamamlanmıştır. Bu planlama tekniğinde işlemler için kesin bir süre tahmini yapılamadığı için olasılık hesabına dayanan iyimser, kötümser ve olası süre olmak üzere 3 farklı süre tahmini yapılmaktadır. Her işlem için yapılan bu süre tahminleri ile işlem sürelerinin ortalama değerleri olasılık olarak tespit edilerek projedeki belirsizliklerin en düşük seviyeye indirgenmesi amaçlanmaktadır. Bu nedenle PERT tekniği olasılık arz eden projelerde kullanılmaktadır (Pontrandolfo, 2000). Özetle, PERT yönetim tekniği planlanması yapılan bir projede işlemleri, işlemlerin başlangıç-bitiş sürelerini, işlemlerin uygulama sırasını, hangi işlemlerin aynı anda yapılabileceğini olasılıklar dâhilinde paydaşlara görsel olarak anlatmaya yarar.

\section{PERT Diyagramı İslem Hesabı}

Bu teknikte her işlem için (Ünder, 2006);

- $t_{a}=$ iyimser süre,

- $\quad t_{b}=$ kötümser süre,

- $\quad \mathrm{t}_{\mathrm{m}}=$ olası süre, $\mathrm{t}_{\mathrm{e}}=$ ortalama süreyi

ifade etmekte olup

- $\mathrm{t}_{\mathrm{e}}=\left(\mathrm{t}_{\mathrm{a}}+4 \mathrm{t}_{\mathrm{m}}+\mathrm{t}_{\mathrm{b}}\right) / 6$

şeklinde bulunarak şebeke hesabında bu $\left(t_{e}\right)$ değeri esas alınmaktadır.

Bir projede işlemleri, işlemlerin başlangıç-bitiş zamanları, işlemlerin uygulama sırası, hangi işlemlerin aynı anda yapılabileceği belirlendikten sonra PERT Diyagramı oluşturulmaktadır. Şekil 6'daki PERT Diyagramı örneğinde kalın çizgi kritik yolu temsil etmektedir. Bu çizgi, işlemlerin hiçbirinde bolluk olmadığını, bu işlemlerdeki herhangi bir gecikmenin programın tamamlanma tarihini geciktireceğini, projede süre ve maliyet bakımından tasarruf edilmek isteniyorsa kritik yoldaki işlemlerin iyileştirilmesini ifade etmektedir (Kızıl, 2020). Bu teknik sayesinde işlem süreleri hakkında net bilgi edinilemeyen projelerin planlaması ve kontrol edilmesi kolaylaşmıştır. Ancak projenin yapısına göre Tablo 2'de de görüldüğü üzere kullanıcıya avantajlar ve dezavantajlar oluşturabilmektedir. 


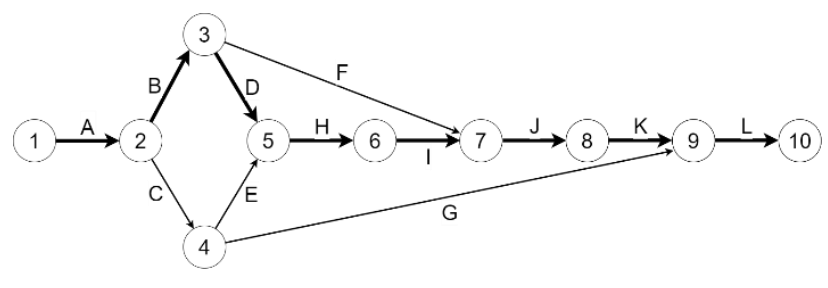

Şekil 6. PERT Diyagramı Örneği (Kızıl, 2020)

Tablo 2. PERT Tekniğinin Avantaj ve Dezavantajları (Coşkun ve Ekmekçi, 2012, Dunne ve Klementowski, 1982, Ünder, 2006, Temel, 2011, Bakışkan, 2019).

\section{ÜSTÜNLÜKLER}

Projenin planlanması, Projelerde bu yöntemi programlaması ve kontrolü kullanacak olanların proje için tutarlı bir çerçeve işlemlerini açık bir şekilde oluşturur. Projedeki işlemler oldukça titizlikle ve dikkatle hakkında maliyet olarak hazırlamaları gerekir.

kullanıcıya fikir verir.

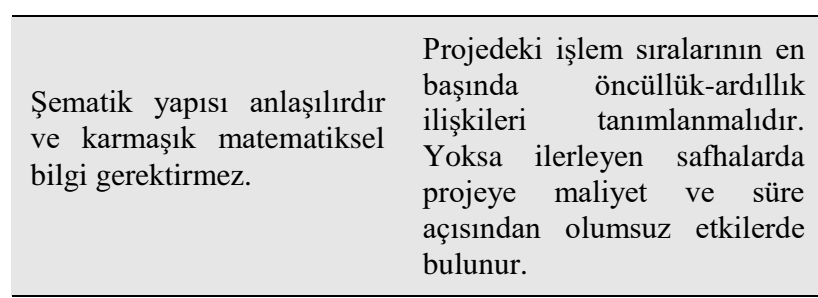

İşlem ilişkilerinin tek Proje süresince başta bakışta görsel olarak ifade belirlenen kritik yol odak edilebilmesi işlemler noktası olacağı için, kritik yola arasındaki ilişkilerin yakın yollar da dikkatle takip anlaşılmasını kolaylaştırır. edilmelidir.
İterasyonlar sonucu projelerin tahmini bitirilme sürelerini hesaplamaya yardımcı olur.

İşlemlerin başlangıç ve bitiş zamanlarını açıkça ifade eder.

Proje paydaşları arasındaki iletişimi kolaylaştırdığından çok paydaşlı projelerde kullanışlıdır.

Küçük hacimli projelerde kullanılamaz çünkü küçük projeler için gereğinden fazla karmaşıktır.

Projedeki her işlemin üç farklı zaman dilimine göre hesaplanması farklı verilerin oluşmasına neden olmaktadır. $\mathrm{Bu}$ durum projedeki hata oranin artmasina yol açabilmektedir.

Kullanılan diğer proje tekniklerine göre daha fazla hesaplama yapıldı ̆̆ için ortaya çıkan veri sayısı da artmaktadır. $\mathrm{Bu}$ durum sistemin maliyetini yükseltmektedir.

\section{CPM-Kritik Yol Yöntemi (Critical Path Method)}

CPM tekniği karmaşık ve büyük ölçekli projelerin analiz edilmesi, planlanması ve kontrol edilmesi için geliştirilen, projedeki işlemlerin düşük maliyetle ve hedeflenen zamanda tamamlanması için gereken kritik yolun oluşturulmasını sağlayan bir tekniktir. İlk olarak 1950 yılında bir tesis bakım projesinde uygulanmıştır. Bu teknik sayesinde projelerdeki işlemlerin öncelik sırası belirlenir ve işlem sürelerinin kesin olarak bilinebilmesi sayesinde bir zaman diyagramı oluşturulur (Yıldız, 2015). CPM tekniğinde, planlama ve uygulama için Gantt Diyagramına göre daha fazla hesaplama yapılması, tekniğin karmaşık hale gelmesine neden olmaktadır. Buna rağmen verimli sonuçlar alınabilmektedir. Özetle, CPM tekniği, kapsamlı ve karmaşık yapıdaki projelerin planlanması ve kontrol edilmesinde kullanılması durumunda sağlıklı sonuçlar veren bir proje yönetim tekniğidir. Dolayısıyla bir projenin CPM diyagramı işlemleri, ilişkilerini ve sürelerini bütün bir halde göstererek proje paydaşlarına sunmaktadır. Bu nedenle bu teknik inşaat sektöründe siklıkla kullanılmaktadır. Deterministik bir teknik olan CPM kullanılarak projeyle ilgili aşağıdaki sorulara cevap verilebilmektedir (Kızıl, 2020):

- Projenin tamamlanması için gerekli olan en kısa süre ne kadardir?

- Her bir işlemin başlayabileceği en erken zaman nedir?

- Projenin kritik işlemleri ve bolluk süreleri hangileridir?

- Projenin en kısa sürede bitmesi için işlemlerin en geç tamamlanma süresi ne kadardır?

CPM tekniğinde projede yapılan işlem türleri

- hem zaman hem kaynak harcayan,

- sadece zaman harcayan,

- kukla işlemler

olarak sıralanmaktadır. Tablo 3'te gerçek ve yapay işlemler düğüm noktaları arasında sürekli bir ok ile gösterilirken; kukla işlemler düğüm noktaları arasında kesikli bir ok yardımı ile tanımlanır (Ünder, 2006).

Tablo 3. Örnek CPM İşlem Tanımı (Açıkel vd., 2013).

\begin{tabular}{|c|c|c|c|c|}
\hline $\begin{array}{c}\text { Isşlemin } \\
\text { Gösterimi }\end{array}$ & $\begin{array}{c}\text { Süre } \\
(\mathrm{t})\end{array}$ & $\begin{array}{c}\text { Yapılan } \\
\text { İşs }\end{array}$ & Adı & Örnek \\
\hline$\longrightarrow$ & + & + & İşlem & $\begin{array}{c}\text { Duvar } \\
\text { Örme } \\
\text { Beton } \\
\text { Dökme }\end{array}$ \\
\hline$\longrightarrow$ & + & - & $\begin{array}{c}\text { Süre } \\
\text { İşlemi }\end{array}$ & $\begin{array}{c}\text { Kalıp } \\
\text { Bekleme } \\
\text { Boya } \\
\text { Kurumas }\end{array}$ \\
\hline$\bigcirc-\cdot \cdot \rightarrow$ & - & - & $\begin{array}{c}\text { Kukla } \\
\text { İşlem }\end{array}$ & - \\
\hline
\end{tabular}

CPM tekniği kullanılarak oluşturulan diyagramlar belirli kurallara göre yapılır. Bu kurallar (Açıkel vd., 2013):

- İki düğüm noktası arasında yalnız bir işlem tanımlanmalıdır.

- Diyagramda bir başlangıç ve bir bitiş düğüm noktası olmalidir.

- Detaylı inceleme için ana diyagramdan bir işlem alınarak bir alt diyagram oluşturulduğunda, alt 
diyagramın başlangıç ve bitiş düğümleri ana diyagramınkilerle çakışmalıdır.

- İşlemler arasında öncüllük-ardıllık ilişkileri kurulurken mantıksal hata yapılmamalıdır.

- Diyagramda oluşturulan düğüm noktaları numaralandirılırken bir numara birden fazla sefer kullanılmamalıdır.

Diğer proje yönetim tekniklerinde olduğu gibi CPM tekniği de yapılan projenin detaylarına bağlı olarak bazı noktalarda kullanıciya avantaj ve dezavantaj sağlamaktadır (Tablo 4).

Tablo 4. CPM Tekniğinin Avantaj ve Dezavantajları (Coşkun ve Ekmekçi, 2012, Ünder, 2006, Temel, 2011, Trietsch ve Baker, 2012, Bakışkan, 2019).

\begin{tabular}{|c|c|}
\hline LÜKLER & ZAYIFLIKLAR \\
\hline $\begin{array}{l}\text { Projedeki iş akış sırasını ve } \\
\text { işlemler arasındaki ilişkileri } \\
\text { kapsamlı ve tutarlı bir } \\
\text { şekilde gösterir. }\end{array}$ & $\begin{array}{l}\text { Olası tamamlanma süresini } \\
\text { hesaplamak için kullanılan } \\
\text { bir formül yoktur. Bu } \\
\text { nedenle fazla olasılık içeren } \\
\text { projelerde hata payı } \\
\text { artmaktadır. }\end{array}$ \\
\hline $\begin{array}{l}\text { Projedeki işlemlerin süresini } \\
\text { hesaplamada sadece bir tane } \\
\text { süre tahmini yapılarak } \\
\text { karmaşı hesapların önüne } \\
\text { geçilmektedir. }\end{array}$ & $\begin{array}{l}\text { Yapılan projenin büyük ve } \\
\text { karmaşı olması yapılacak } \\
\text { işlem sayısını artıracağı için } \\
\text { projedeki küçük hataların } \\
\text { toplamı projenin durumunu } \\
\text { olumsuz } \\
\text { etkileyebilmektedir. }\end{array}$ \\
\hline $\begin{array}{l}\text { Projede yapılan } \\
\text { değişiklikler, bu tekniğin } \\
\text { dijital ortamda kullanılması } \\
\text { sayesinde kolaylikla } \\
\text { diyagramlara aktarılabilir. } \\
\text { Ayrı projede yapılan } \\
\text { değişiklikler için gereken } \\
\text { kaynaklar diyagramdan } \\
\text { tahmin edilebilir. }\end{array}$ & $\begin{array}{l}\text { Bu tekniğin kullanımının ve } \\
\text { anlatılmasının zor olması, } \\
\text { programın proje paydaşları } \\
\text { tarafından karmaşı olarak } \\
\text { algılanmasına neden } \\
\text { olabilir. Bu durum projenin } \\
\text { paydaşlarını ve müşterilerini } \\
\text { olumsuz anlamda } \\
\text { etkileyebilir. }\end{array}$ \\
\hline $\begin{array}{l}\text { Projelerin kalite, maliyet ve } \\
\text { süre açısından hedefine } \\
\text { ulaşması için hazırlanan } \\
\text { planlarda } \\
\text { alternatif seçenekler sunar. }\end{array}$ & 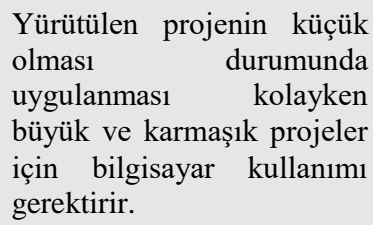 \\
\hline
\end{tabular}

Projelerdeki işlemler açık bir şekilde tanımlandığı için istenildiğinde yeni süre tahminleri yapma imkânı vermektedir.

Orta büyüklükteki projelerin planlaması ve kontrolünde bile bilgisayar kullanımı gerektirmektedir.

Etkin bir planlama ve kontrol sayesinde proje maliyetleri azaltılabilir.

CPM tekniği, Gantt diyagramlarına göre daha maliyetlidir.

İşlemlerin diyagramlarla ifade edilmesi karmaşık projeler için kullanım kolaylığı sağlar.
Projelerin planlama ve kontrol arac1 olarak kullanılması, fazla veri kullanımını gerektirdiğinden bilgisayar kullanımını gerekli kılar.

\subsection{PERT ve CPM Tekniklerinin Karşılaştırılması}

Faaliyet sürelerinin belirlenmesi haricinde proje diyagramının çizilmesi ve işlemlerin başlangıç-bitiş zamanlarının hesaplanması her iki teknikte de aynı şekilde yapılmaktadır. Ancak söz konusu teknikler arasındaki en önemli fark, PERT tekniğinin süre ve maliyet açısından kesinlik ifade etmeyen projeler için hazırlanmış olmasıdır (Yalk1, 2009).

Tablo 5. CPM ve PERT Tekniklerinin Karşılaştırılması (Ünder, 2006, Temel, 2011, Trietsch ve Baker, 2012).

\begin{tabular}{|c|c|}
\hline PERT & СРМ \\
\hline $\begin{array}{l}\text { Her bir işlemin süresi } \\
\text { hesaplanırken üç farklı zaman } \\
\text { kullanılır. }\end{array}$ & $\begin{array}{l}\text { Her bir işlemin } \\
\text { hesäresi } \\
\text { kullanılır. }\end{array}$ \\
\hline $\begin{array}{l}\text { Üç farklı zaman } \\
\text { kullanımından dolayı daha } \\
\text { fazla olasılık barındırır. }\end{array}$ & $\begin{array}{l}\text { Projede yer alan faaliyet } \\
\text { süreleri kesin } \\
\text { belirlenebilir. }\end{array}$ \\
\hline $\begin{array}{l}\text { İlk kez yapılacak olan ve } \\
\text { kesinlik belirtmeyen projeler } \\
\text { için kullanılmaktadır. }\end{array}$ & $\begin{array}{l}\text { Önceki projelerde yürütülen } \\
\text { işlemleri barındıran yeni } \\
\text { projeler için kullanılan bir } \\
\text { yöntemdir. }\end{array}$ \\
\hline $\begin{array}{l}\text { Süreler kesin olmadığından } \\
\text { maliyet analizi çok sağlıklı } \\
\text { sonuçlar vermemektedir. }\end{array}$ & $\begin{array}{l}\text { CPM yönteminde süreler } \\
\text { kesin olarak belirlenebildiği } \\
\text { için maliyet analizleri } \\
\text { sağliklı } \\
\text { vermektedir. }\end{array}$ \\
\hline
\end{tabular}

\section{SONUÇ}

Yapı sektörü, içerisinde barındırdığı bileşenlerin ve dinamiklerin, küreselleşme, değişen koşullar ve artan rekabet ortamında değişen şartlara uygun pozisyon almak durumundadır. $\mathrm{Bu}$ sebeple, projelerin etkin ve verimli olarak yürütülmesini sağlamak için çeşitli proje yönetim teknikleri geliştirilmiştir. Geliştirilen proje yönetimi ve teknikleri sektöre olumlu katkı yaparken projelerin giderek kapsamlı ve karmaşık hâle gelmesi, istenen hedeflere ulaşılmasında birtakım zorlukları ve sorunları beraberinde getirmektedir. Ortaya çıkan sorunları gelişen teknoloji ve teknikler ile çözüme kavuşturmaya çalışan firmalar, proje yönetimi ve proje yönetim tekniklerini etkin kullanarak uygulamalarını daha kısa sürede hedefe ulaştırmaya, proje maliyetlerini kaliteden ödün vermeden en düşük seviyeye indirgemeye ve belirli bir kâr payı elde etmeye çalışmaktadır. Dolayısıyla bu yaklaşımı benimseyen firmalar, projelerde belirlenen hedeflere ulaşmak için yapılacak olan projenin türünü, içeriğini, büyüklüğünü, taşıdığı riskleri ve sürece dâhil olan paydaşların görev ve sorumluluklarını proje yöneticileri eliyle uygun bir şekilde belirlemelidir. Ardından projenin planlama, uygulama ve kontrol süreçlerinde hangi teknik ve yöntemlerin kullanılacağına doğru bir şekilde karar vermelidir. Aksi durumlarda projenin planlamasında kullanılan yanlış teknikler ve hatalı uygulamalar projenin kalite, maliyet ve süre açısından kayıp yaşamasına neden olabilmektedir. (Pellerin ve Perrier, 2018) Projelerin planlama, uygulama ve kontrol aşamasında kullanılan ve bu çalışmada detaylı bir şekilde incelenen Gantt Diyagramı, CPM ve PERT teknikleri sayesinde projelerde yapılacak olan faaliyetleri, işlem sıralarını, kritik olan ve olmayan yolları ve işlem 
zamanlarını ortaya koyan bir işlem diyagramı oluşturulup projelerde kaynak, tedarik, maliyet ve süre yönetimi yapılarak proje sürecinin sağlıklı bir şekilde yürütülmesi ve projelerin istenen hedefe ulaşması sağlanmalıdır. Bu nedenle çalışmada da detaylı şekilde ifade edilen Gantt Diyagramı, CPM ve PERT tekniklerinin projelerde kullanılması;

- Projedeki kritik yolun belirlenmesine ve hangi işlemler üzerinde gecikme yaşanmaması gerektiğine karar verilmesine,

- Projelerde herhangi bir olumsuz durum yaşanması halinde belirlenen kritik yollara kaynak aktarımı yapılıp iyileştirilerek projelerde maliyet ve süreden tasarruf edilmesine,

- Projelerdeki her adımın incelenmesine imkân vermesi sayesinde projedeki verimliliğin ve performansın artmasina,

- Projelerde planlanan sürecin maliyet ve süre bakımından sağlıklı bir şekilde yürütülmesine,

- Mevcut kaynakları projede hedeflenen süre ve maliyete uygun kullanarak projenin kontrolünün sağlanmasına yardımcı olacaktır.

Ancak yapılan literatür araştırmaları kapsamında; projelerin kendilerine özgü farklı şartlar barındırmasından doğan organizasyon stratejilerinin farklılaşması, küçük hacimli projelerde hâlâ geleneksel yöntemlerin kullanılması, kullanılan tekniklerin avantaj-dezavantajları ve kullanım alanları gibi durumların proje yürütücüleri veya küçük ölçekli yatırımcı tarafından göz ardı edilmesi hatalı proje yönetimine yol açarak sektörde olumsuz etki yaratabilmektedir. Yapılan araştırmalar ve değerlendirmeler doğrultusunda proje yönetimi ve proje yönetim tekniklerinin önemi, detaylı özellikleri, kullanım alanlarının doğru belirlenmesi ve yaygın kullanımının teşvik edilmesi;

- Süre ve maliyet tasarrufu sağlanacağı için sektörde pozitif bir büyümeye,

- Projelere dâhil olan tüm paydaşlara proje yönetim bilincinin kazandırılması noktasında projelerdeki organizasyonel yetkinliğin artmasına,

- Geleneksel yöntemlerle proje yürütenlerin uygulamalarda daha başarılı olması için proje içeriği ve hedeflerinin iyi belirlenmesi ile ilgili sektörel okuryazarlığın artırılması ve böylece kalite, maliyet ve süre kaybının yaşanmasının önlenmesine,

- İlgili departmanlarda, proje süreci içerisinde proje yönetim tekniklerinin yanlış uygulaması sonucu ortaya çıkan problemlerin önlenmesine,

- Sektörde kullanılan CPM, PERT ve Gantt Diyagramlarının avantaj ve dezavantajlarının iyi bir şekilde tespit edilip projelerde kullanılmasına

fayda sağlayacaktır.

$\mathrm{Bu}$ kapsamda, karmaşık olmayan ve görece basit, başlangıç ve bitiş tarihi belli işlemler içeren, hızlı güncelleme ihtiyacı duyulan projelerde çubuk (Gannt) diyagramı tekniğinin; görece daha fazla işlem içeren, ancak daha önce yürütülmediği için süreleri tahmin yoluyla belirlenecek işlemleri barındıran projelerde PERT tekniğinin; işlemlerin sürelerinin, önceki deneyimler sayesinde kesin olarak belirlenebildiği, takip ve yönetimin kritik öneme sahip olduğu görece karmaşı projelerde CPM tekniğinin kullanılmasının uygun olduğu değerlendirilmektedir.

Sonuç olarak, elde edilen bulgular doğrultusunda etkili bir proje yönetimi; yapılması düşünülen projenin iyi bir şekilde tanımlanması, nicel ve nitel olarak analiz edilmesi, proje evrelerini oluşturan planlama, uygulama, kontrol ve gözden geçirme aşamalarının planlanması ve projenin hedeflerine ulaştırılması için kullanılacak olan tekniğin avantaj-dezavantajları göz önünde bulundurularak uygun proje yönetim tekniğinin seçilmesi gibi faaliyetleri kapsamaktadır. Çalışmanın amacını teşkil eden bu yaklaşımla, çeşitli yazılı kaynaklarda yukarıda ifade edilen tekniklerle ilgili çalışmalar birbirleriyle karşılaştırılıp inşaat sektöründe proje yönetimi ve yaygın olarak kullanılan tekniklerin proje hedefine ulaşmasında sağladığı yararları, önemleri ve avantaj-dezavantajları ortaya konularak ilgili firmalara ve bu alanda akademik olarak çalışmalar yürütenlere bir yol gösterici olması hedeflenmiştir.

\section{Teşekkür ve Bilgi Notu}

Makalede ulusal ve uluslararası araştırma ve yayın etiğine uyulmuştur.

\section{Yazar Katkısı ve Çıkar Çatışması Beyan Bilgisi}

Makalede tüm yazarlar eşit derecede katkıda bulunmuşlardır. Araştırmada herhangi bir çıkar çatışması bulunmamaktadir.

\section{KAYNAKÇA}

Açıkel, D.A., Altın, M., Açıkel, H., (2013). Yapı Işsletmesi ve Şantiye Yönetimi, Eğitim Yayınevi, Konya, 7-8.

Albayrak, B., (2009). Proje Yönetimi, Nobel Yayın Dağıtım, Ankara.

Bakışkan E., (2019). CPM-PERT Proje Yönetim Tekniklerinin Karadeniz Tipi Balıkçı Gemileri İnşa Sürecine Uygulanması, Karadeniz Teknik Üniversitesi, Fen Bilimleri Enstitüsü, Trabzon.

Cleland, D.I., Ireland, L.R., (2002). Project Management, Strategic Decisionand Implementation. 4. Bask1, McGrawHill, Boston, 170-321.

Copertari, L.F., (2002). Time, Cost and Performance Tradeoffs in Project Management, Doktora Tezi, McMaster Üniversitesi, Ontario.

Coşkun O., Ekmekçi İ., (2012). Bir İnşaat Projesinin Evreleri İle Zaman ve Maliyet Analizinin Proje Yönetim Teknikleri Vasıtasıyla İncelenmesi, İstanbul Ticaret Üniversitesi Fen Bilimleri Dergisi, 20, 39-53.

Dunne, E. J., Klementowski, L.J. (1982). An Investigation of The Use of Network Techniques in Research and Development Management, IEEE Transactions On Engineering Management, 29(3), 77.

Gültekin, A.T., (2007). Proje Yönetimi Yapım Öncesi Süreci, Palme Yayıncılık, Ankara, 64. 
Halaç, O., (2001). Kantitatif Karar Verme Teknikleri Yöneylem Araştırması, Alfa Basım Yayım Dağıtım, İstanbul.

Kerzner, H., (2003). Project Management A System Approach to Planning, Scheduling, and Controlling, 8.Bask1, John Wiley \& Sons Inc., 387-388.

Kır, E., (2007). Yazılım Sektöründe Proje Yönetimi, Yüksek Lisans Tezi, Kadir Has Üniversitesi, Sosyal Bilimler Enstitüsü, İstanbul.

Kızıl F., (2020). İnsansız Hava Aracı (İHA) Yapımının Proje Değerlendirme ve Gözden Geçirme Tekniği (PERT) ile Planlanmasi, Anadolu Üniversitesi, Sosyal Bilimler Enstitüsü, Eskişehir.

Kömürlü R., Toltar L., (2018). İnşaatta Proje Yönetimi; Projenin Başarısına Etkisi (Project Management in Construction and Its Effect on Project's Success), Mimarlık ve Yaşam Dergisi, 3(2), 249-258.

Pellerin, R., Perrier, N., (2018). A Review of Methods, Techniques and Tools for Project Planning and Control, International Journal of Production Research, 57(7), 2160-2178.

PMBOK, (2000). A Guide to the Project Management Body of Knowledge, Newton Square:Project Management Institute.

PMBOK, (2013). A Guide to the Project Management Body of Knowledge Proje Yönetimi Bilgi Birikimi Kllavuzu, 5. Bask1, PMI Project Management Institute, İstanbul.

Pontrandolfo, P., (2000) Project duration in stochastic networks by the PERT-path technique, International Journal of Project Management, 18(3), 215-222.

Starr, M.K., (1996). Operation management A System Approach, First Published, Boyd \& Fraser Pub Co., San Francisco.

Taxen, L., Lilliesköld, J., (2008). Images as action instruments in complex projects, International Journal of Project Management, 26(5), 527-536.

Temel, M., (2011). Proje Yönetimi Teknikleri ve Kara Salyangozu Üretim Çiftliği Projesi Üzerine Bir Uygulama, Çukurova Üniversitesi, Sosyal Bilimler Enstitüsü, Adana.

Trietsch, D., Baker, K.R., (2012). PERT 21: Fitting PERT/CPM for use in the 21st century, International Journal of Project Management, 30(4), 490-502.

Ünder, M.B., (2006). İnşaat İşletmelerinde Proje Yönetimi ve Bilgi Teknolojileri Uygulamaları, İstanbul Üniversitesi, Sosyal Bilimler Enstitüsü, İstanbul.

Yalk1 İ., (2009). Proje Yönetimi ve CPM-PERT Teknikleri Üzerine Bir Uygulama, Yüksek Lisans Tezi, Marmara Üniversitesi, Sosyal Bilimler Enstitüsü, İstanbul, 240330.

Yıldız A., (2015). Farklı Coğrafi Bölgelerde Petrol Kuyusu Açma Maliyetlerinin PERT-CPM Proje Planlama Teknikleri ile Karşılaştırılmalı Analizi, Yüksek Lisans Tezi, Gazi Üniversitesi, Sosyal Bilimler Enstitüsü, Ankara. 